\title{
Research on Evaluation and Improvement Path of Core Competitiveness of China's Small and Medium-sized Joint-stock Commercial Banks
}

\author{
Yongxia Bao \\ School of Economy and Management, Beijing Jiaotong University, Beijing 100044, China
}

Keywords: Core Competitiveness; Commercial Banks; Evaluation; Improvement Path.

\begin{abstract}
In order to evaluate and improve the core competitiveness of China's small and medium-sized joint-stock commercial banks, the paper come up with new ideas. This paper firstly retrospects the competitiveness and development of bank industry. And then the paper has built a new assessment indicator system to make evaluation competitiveness of middle and small-sized joint-stock commercial banks. After a brief analysis of the quantitative indicators of the eight banks, this paper weighted and ranked each bank according to the proportion of each evaluation index. Moreover, this paper compared human resource systems and product innovation ability of 8 small and medium-sized joint-stock commercial banks. At the end of this paper, we can be aware of the universal problems of these banks and propose three suggestions to promote competitiveness of them. The improving path includes improving the capabilities of banks to withstand risks; completing promotion and stimulation system and persisting products innovation.
\end{abstract}

\section{Introduction}

The research object of this paper is small and medium-sized joint-stock commercial banks. There are 8 national small and medium-sized joint-stock commercial banks in China. Joint-stock commercial banks have a clear structure of property rights, which also determines the characteristics of their own operations and self-financing. However, it is easy to see that even if a small share commercial bank is reforming and is committed to meeting the specific needs of a particular customer, the innovative products and services are approximately similar, and the cycle of innovation is longer.

The research on the core competitiveness of small and medium-sized joint-stock commercial banks is a further deepening and refinement of the core competitiveness theory of enterprises. The construction of competitiveness index system of commercial banks will be useful in related research.

The main content of this paper is to analyze the development status of small and medium-sized commercial banks, and based on the existing core competitiveness related theories. The research results on the core competitiveness of commercial banks, establish a suitable evaluation system for the core competitiveness of banks. The analysis and evaluation of various indicators of small and medium-sized joint-stock commercial banks finally draws relevant conclusions and proposes a path for nurturing and upgrading core competitiveness.

\section{The Evaluation Method and Index System of the Core Competitiveness of China's Commercial Banks}

In the quantitative analysis, the indicators for rating commercial banks in this paper are divided into the following parts: asset quality indicators (40\%), profitability indicators (30\%), and development capacity indicators (30\%). And based on the weights represented by each indicator, final comprehensive score can be gathered. In the qualitative analysis, the selected indicators are human resource management capability indicators, product and service innovation capability indicators. When selecting the research object, this paper intends to select two commercial banks, six joint-stock commercial banks and four city commercial banks for data analysis and ranking. 


\subsection{Asset Quality Indicator}

Asset quality indicators can reflect the quality of commercial banks' assets, which is a key dimension in the competitiveness of the banking industry. The asset quality indicators selected in this paper include current ratio, deposit-loan ratio, non-performing asset ratio, and total capacity turnover rate.

\subsection{Profitability indicator}

The stronger the profitability of a commercial bank, the higher the profit that a commercial bank can achieve, and the greater its competitiveness. Profitability is a necessary indicator for analyzing the competitive situation of each company. When analyzing the profitability of commercial banks, the three indicators used in this paper are: cost expense profit rate, total return on assets, and return on net assets.

\subsection{Development capacity indicator}

The development capability indicators can reflect the future growth and strength of the company in the current situation. The development capability indicators adopted in this paper are the operating income growth rate, the capital accumulation rate and the total asset growth rate.

\subsection{Human resource management indicators}

The competition between enterprises is also the competition of talents. In commercial bank industry, human resource management is also important. In this paper, the indicators for the evaluation of human resources ability of commercial banks are mainly divided into: employee training and incentive mechanism, and employee performance management mechanism. By analyzing the training and incentive mechanisms of various banks, we can draw the talent training and promotion mechanism of various commercial banks, and attach importance to various talents.

\subsection{Product and service innovation indicators}

With the serious homogenization of commercial banks, the innovation of financial products and services has become an inevitable factor in their competition. At present, many products launched by commercial banks have strong homogeneity, which makes banks unable to stand out from the competition.

\section{Evaluation of the Core Competence of 8 Joint-stock Commercial Banks in China}

The research steps in this part can be concluded into two parts. Firstly, analyzing the financial statements of each bank through quantitative analysis and calculate the scores of each indicator. Secondly, through qualitative analysis, the paper analyzes the qualitative indicators of each bank, and finally finds out the problems faced by small and medium-sized joint-stock commercial banks in the competitive environment, and lays a good foundation for the improvement of competitiveness in the following.

\subsection{Quantitative index analysis}

Quantitative analysis refers to the analysis of the financial statements of commercial banks to obtain relevant evaluations of their asset quality, profitability and development potential. In this paper, two state-owned commercial banks and six small and medium-sized joint-stock commercial banks were selected for comparison.

\subsubsection{Comparison of current ratio}

Judging from the calculated data (Table 1), there are some differences in the magnitude and direction of changes in the flow rates of small and medium-sized banks in the past five years. Among them, the liquidity ratio of China CITIC Bank, China Merchants Bank and Ping an Bank has been decreasing from 2014 to 2016; while the liquidity ratios of Industrial Bank, Hua Xia Bank and Shanghai Pudong Development Bank have decreased in 2012 and then increased. The reason is that the former is due to the decrease in the current bank's current assets or the ratio of current assets to current liabilities from 2014 to 2016 . The latter banks have done a better job in the retail business, strengthening the ratio of corporate liquidity.

Table 1 Comparison of current ratio

\begin{tabular}{|c|c|c|c|c|c|}
\hline Report Date & $2016 / 9 / 30$ & $2015 / 12 / 31$ & $2014 / 12 / 31$ & $2013 / 12 / 31$ & $2012 / 12 / 31$ \\
\hline ICBC & 0.238 & 0.256 & 0.266 & 0.263 & 0.265 \\
\hline Bank of China & 0.198 & 0.203 & 0.223 & 0.246 & 0.230 \\
\hline
\end{tabular}




\begin{tabular}{|c|c|c|c|c|c|}
\hline \multicolumn{7}{|c|}{ Cont. To Table 1 } \\
\hline CITIC Bank & 0.174 & 0.188 & 0.217 & 0.284 & 0.252 \\
\hline $\begin{array}{c}\text { China Merchants } \\
\text { Bank }\end{array}$ & 0.203 & 0.252 & 0.280 & 0.283 & 0.233 \\
\hline Industrial Bank & 0.227 & 0.191 & 0.349 & 0.443 & 0.482 \\
\hline Ping An Bank & 0.204 & 0.251 & 0.291 & 0.317 & 0.329 \\
\hline HSBC Bank & 0.257 & 0.309 & 0.264 & 0.399 & 0.367 \\
\hline $\begin{array}{c}\text { Shanghai Pudong } \\
\text { Development Bank }\end{array}$ & 0.193 & 0.191 & 0.210 & 0.253 & 0.286 \\
\hline
\end{tabular}

\subsubsection{Comparison of capital accumulation rates}

Capital accumulation rates are shown in Fig. 1 Except for China Merchants Bank and Ping An Bank, the trend of capital accumulation rate of other commercial banks is consistent. In general, the capital accumulation rate of the eight banks as research objects has exceeded $10 \%$ in recent years.

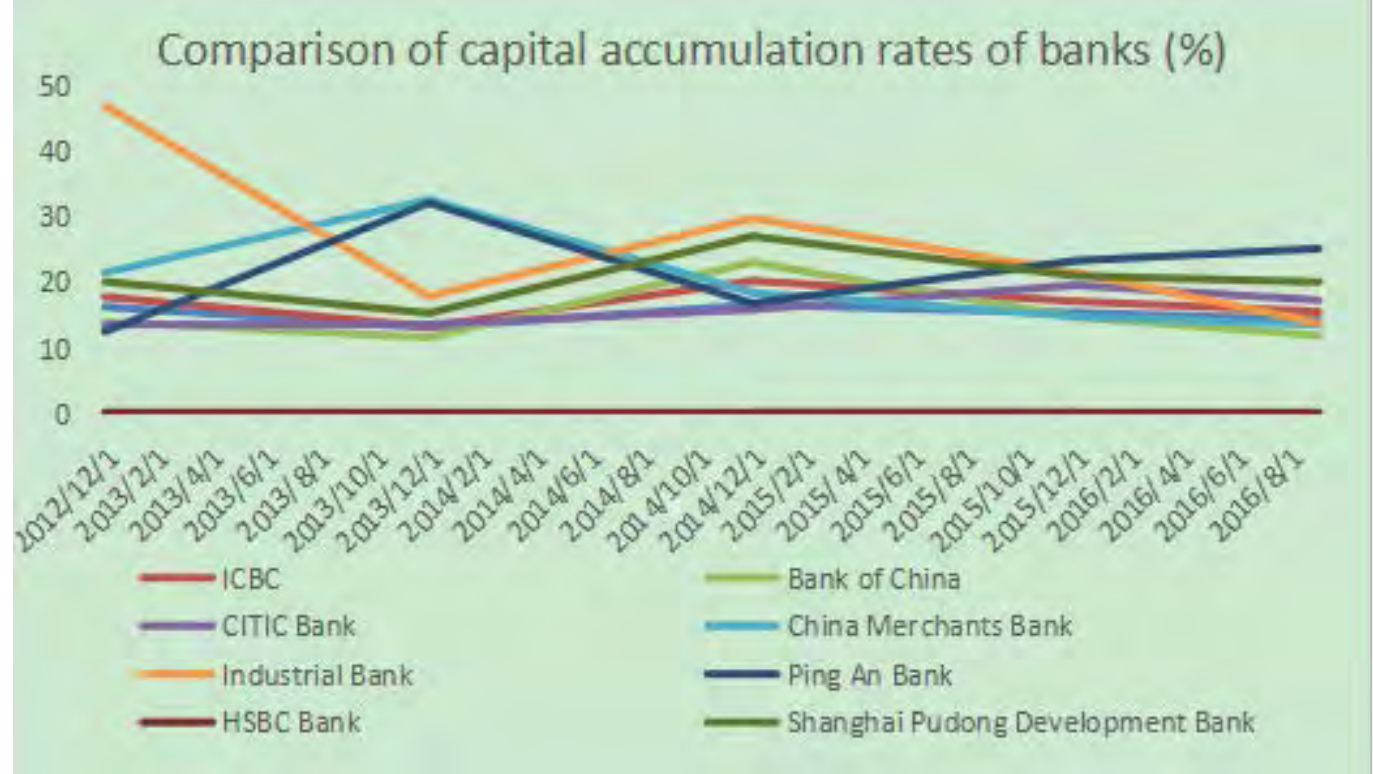

Fig. 1 Comparison of capital accumulation rates of banks (\%)

\subsubsection{Comparison of capital adequacy ratio}

According to the Basel Accord, the bank's risk capital adequacy ratio should be 8\%, which means that if the bank's asset-liability ratio is below 92\%, it is at a normal level. According to the financial statements of each bank, the asset-liability ratio of the joint-stock commercial banks in the research sample exceeded $92 \%$. The capital adequacy ratio of state-owned commercial banks is at the forefront, and joint-stock commercial banks are at a disadvantage. Fortunately, Industrial Bank, China CITIC Bank, Shanghai Pudong Development Bank and Hua Xia Bank respectively financed and expanded their shares in order to ensure capital adequacy ratio: Industrial Bank completed 24 billion financing in early 2013, and CITIC Bank was approved to issue no more than 30 billion financial bonds. Expansion of capital, Shanghai Pudong Development Bank began to raise funds of 14.8 billion in March 2016 to expand Tier 1 capital. With the support of government policies, small and medium-sized commercial banks are developing their capital adequacy ratio in a more stable direction. Table 2 shows the Comparison of asset-liability ratio of joint-stock commercial banks.

Table 2 Comparison of asset-liability ratio of joint-stock commercial banks

\begin{tabular}{|c|c|c|c|c|c|}
\hline Report Date & $2016 / 9 / 30$ & $2015 / 12 / 31$ & $2014 / 12 / 31$ & $2013 / 12 / 31$ & $2012 / 12 / 31$ \\
\hline ICBC & 91.74 & 91.89 & 92.54 & 93.24 & 93.57 \\
\hline Bank of China & 91.8 & 91.93 & 92.24 & 93.07 & 93.21 \\
\hline CITIC Bank & 93.73 & 93.76 & 93.54 & 93.66 & 93.14 \\
\hline $\begin{array}{c}\text { China Merchants } \\
\text { Bank }\end{array}$ & 92.86 & 93.39 & 93.34 & 93.38 & 94.12 \\
\hline
\end{tabular}




\begin{tabular}{|c|c|c|c|c|c|}
\hline \multicolumn{7}{|c|}{ Cont. To Table 2 } \\
\hline Industrial Bank & 94.02 & 94.01 & 94.07 & 94.53 & 94.75 \\
\hline Ping An Bank & 93.15 & 93.56 & 94.01 & 94.08 & 94.72 \\
\hline HSBC Bank & 93.44 & 94.14 & 94.49 & 94.86 & 94.98 \\
\hline $\begin{array}{c}\text { Shanghai Pudong } \\
\text { Development Bank }\end{array}$ & 93.45 & 93.68 & 93.73 & 94.37 & 94.29 \\
\hline
\end{tabular}

After a brief analysis of the quantitative indicators of the eight banks, this paper will weight and rank each bank according to the proportion of each evaluation index.

Table 3 Bank Ranking

\begin{tabular}{|c|c|c|}
\hline Bank & Quantitative indicator score & Ranking \\
\hline ICBC & 0.3043 & 2 \\
\hline Bank of China & 0.2760 & 3 \\
\hline CITIC Bank & 0.2457 & 8 \\
\hline China Merchants Bank & 0.2678 & 5 \\
\hline Industrial Bank & 0.2757 & 4 \\
\hline Ping An Bank & 0.2515 & 7 \\
\hline HSBC Bank & 0.2547 & 6 \\
\hline Shanghai Pudong Development Bank & 0.3123 & 1 \\
\hline
\end{tabular}

\subsection{Qualitative indicator analysis}

\subsubsection{Human resource management indicators}

In terms of talent development, state-owned banks have established a relatively complete system of personnel training and promotion based on their various sources of resources and long history. Among the six small and medium-sized joint-stock commercial banks, only China Merchants Bank and China CITIC Bank have established a talent training system with their own characteristics. Other banks have no perfect talent training system.

3.2.2 Product innovation ability and sales ability analysis

In order to study the sales ability of various commercial bank products, this paper studies the issuance of the most representative credit cards of commercial banks from 2014 to 2015 . The specific data is shown in the following figure:

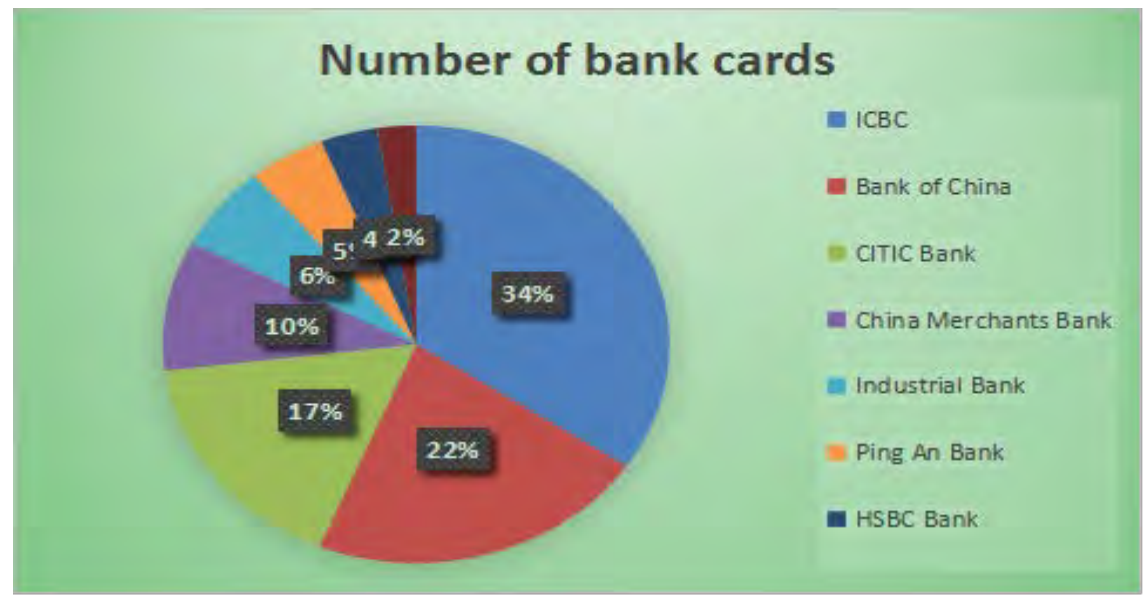

Fig. 2 The issuance of the most representative credit cards in 2015

\section{The main problems in small and medium-sized joint-stock commercial banks}

Small and medium-sized joint-stock commercial banks have low capital adequacy ratio and poor ability to withstand risks in terms of capital management and operational capabilities of enterprises. The skills of many small and medium-sized commercial banks are only based on the basic operations, and there is no research and development capability. Moreover, almost all of the joint-stock commercial banks have a lot of business, 
and even if there is innovation, the business name has been changed simply, and there is no difference in the nature of the business.

\section{Conclusion}

Based on the previous studies, this paper analyzes the development background of small and medium-sized joint-stock commercial banks, summarizes the development of core competitiveness theory, and the authoritative evaluation methods of commercial banks. In the specific evaluation of the core competitiveness of eight joint-stock commercial banks, this paper divides the five indicators into quantitative indicators and qualitative indicators, and then evaluates the development status of small and medium-sized joint-stock commercial banks from quantitative analysis and qualitative analysis. This paper finds out the common problems in their development. In view of the above problems in small and medium-sized joint-stock banks, the following suggestions are given.

(1) Improve corporate governance mechanisms, strengthen the establishment and development of risk management mechanisms for joint-stock commercial banks, and strengthen the assessment of the creditworthiness of credit companies.

(2) Improve the human resources management system structure of commercial banks, form a complete employee induction training, medium-term training system, establish a fair employee evaluation system form a salary system distributed according to work, And it is necessary to form a normal and orderly employee promotion mechanism, fully guaranteeing growth and development of a worker.

(3) Accurately locate the market segments, focus on customer innovation for specific customers, and pay attention to customer feedback on products and services, forming the characteristics and sustainable competitiveness of small and medium-sized joint-stock commercial banks.

\section{References}

[1]. Xingrong Zhang, the three realms of innovation and transformation of listed banks [J]; China Banking Magazine, 2016

[2]. Quan L, Bank C C. Foreign Banks Benchmarked in Promoting Chinese-Funded Banks' Core Competence in Transactional Banking Businesses[J]. Engineering Economy, 2015.

[3]. Prahalad, Hammer. Core Competitiveness of Enterprises [J]; Harvard Business Review 1990

[4]. Carsten Eckel, Leonardo Iacovone, Beata Javorcik, et al. Testing the Core-competency Model of Multi-product Exporters [J]. Review of International Economics, 2016, 24(4):699-716.

[5]. Chen Y, Quanzhou B O. Exploration on the Development Path of City Commercial Banks under the Background of Financial Liberalization Reform-Based on Comparative Advantage Perspective[J]. Journal of Financial Development Research, 2014.

[6]. Yao Cheng. Research on the competitiveness evaluation of China's small and medium-sized joint-stock commercial banks [D]; Shandong University of Finance and Economics master thesis 2013

[7]. Hitt, MichaelA. The management of strategy: concepts and cases / 10th ed[M]. China Renmin University Press, 2012.

[8]. Chen Y. Analysis on the Competitiveness of City Commercial Banks(2009-2016) — On the Perspective of Horizontal Contrast and Dynamic Development[J]. Journal of Contemporary Financial Research, 2017.

[9]. LI-Lei. A Comprehensive Evaluation of Commercial Banks' Core Competitiveness and the Improving Ways[J]. Journal of Hanjiang Normal University, 2017.

[10]. Maolin Sun. Research on the Comprehensive Evaluation of Competitiveness of China's Commercial Banks[D]; Tianjin University Master's Thesis 2012 